\title{
Global climate change responsiveness in the United States of America: an estimation of population coverage and implications for environmental accountants
}

\begin{abstract}
The primary responsibility for global climate change responsiveness is usually attributed to nation states. This is reflected in the United Nations processes aimed at enrolling governments in mitigation and adaptation programmes. Such an approach begs the question of how global climate change responsiveness might proceed if a national government is hostile to the issue, as appears likely to be the case in the United States of America. This paper addresses this concern by documenting the percentage of the population of the United States of America who are 'covered' by at least one of six examples of global climate change responsiveness at sub-federal state and municipality - levels. $25.8 \%$ of the population of the United States of America live in states where all of the state level initiatives surveyed are in effect, whereas only $4.4 \%$ are not covered by any of the six. This coverage has increased as compared to earlier surveys (Lutsey and Sperling, 2008). This finding suggests that there is more practical hope for global climate change responsiveness than might be commonly appreciated and this also has ramifications for research in accounting.
\end{abstract}

Keywords: global climate change; United States of America; population estimates; environmental accounting 


\section{Global climate change responsiveness in the United States of America: an estimation of population coverage}

\section{Introduction}

At the close of 2016 two contrasting forces are in play in the context of global climate change (hereafter GCC) responsiveness. On the positive side, the Paris Agreement (UNFCC, 2015) has become the Paris Declaration and as of $4^{\text {th }}$ November 2016 entered into force. While the full playing out of this agreement is uncertain, it signals a period of likely increased GCC responsiveness by countries, that will be experienced by organisations and individuals (Clémençon, 2016; Morgan, 2016 and Rajamani, 2016, but see also Buxton, 2016 and Spash, 2016 for more negative assessments). At the same time, there is a possible (indeed, likely) negative force at play in the form of President Donald Trump of the United States of America (hereafter USA), who has pledged to repeal the United States Federal Government's engagement with the Paris Declaration and who appears to be sceptical of the existence and ramifications of anthropogenic GCC. Given that the USA collectively accounts for approximately 15\% of global emissions (Netherlands Environmental Assessment Agency, 2015) the prospect of dis-engagement at a federal level is dismaying. However if such an action were taken this would not signal the end of the GCC responsiveness of the USA, as there is already significant responsiveness at a sub-federal level.

With this in mind, this paper seeks to document current GCC responsiveness in the USA at a sub-federal (state and municipality) level. In particular, the paper provides an estimate of the proportions of the US population that are currently living in states 
and/or municipalities that are undertaking one of the six forms of GCC

responsiveness surveyed in this paper. This work complements other studies (Green, et al. 2014; Krause, 2011 and Lutsey and Sperling, 2008) and updates their estimates of proportion of population 'coverage' of GCC responsiveness initiatives.

This paper also speaks to a literature that explores the ongoing evolution of GCC responsiveness with Jordan et al. (2015), noting that 'polycentric' initiatives deserve interrogation. This implies that bodies other than nation states (such as regional authorities, municipalities, industry associations and organizations) are likely to play a role in reducing greenhouse gas emissions and have some agency to enact change. This move towards more 'bottom up' approaches is also evident in the Paris Agreement (see Hermwille et al. 2015 and Morgan, 2016). While being aware of the limitations of such an approach Clémençon (2016) highlights the belief that "domestic constellations in the United States, India, China and many other countries do not support ... top-down internationally determined commitments which would require these countries to move away for long held core negotiating positions" (p. 18). Moreover, it is relevant to note that in the USA "federal and state governments have diverged in their awareness and willingness" (Lutsey and Sperling, 2008, 673) to act on GCC, and hence exploring responsiveness at a sub-federal level is a productive activity. With those points in mind, the paper how moves to explain the data gathering for the argument to be sustained before outlining the relevance of this investigation for accounting scholars.

\section{The GCC responsiveness initiatives surveyed and population estimates}


Six initiatives at state and municipality level were surveyed at the start of 2015 as examples of GCC responsiveness. Of these, four are state level: (i) state legislated greenhouse gas emission targets; (ii) state and/or regional cap and trade schemes; (iii) state greenhouse gas reporting; and (iv) state action plans: and two are municipalitylevel; (v) United States of America Conference of Mayors Climate Protection Agreement (hereafter CMCPA); and (vi) 'C40' Cities Climate Leadership Group. The focus on these initiatives is dictated by a belief that there is a "prescribed pattern [in terms of responsiveness that involves] inventorying ... emissions, establishing climate change action plans, [and] setting emissions reduction targets (Lutsey and Sperling, $2008,673)$. In addition, the focus on states and municipalities is predicated on these entities being powerful enough to influence emissions within their jurisdictions through engagement with their citizens as well as organisations operating in their territories.

Using the data available at http://www.c2es.org/us-states-regions/policy-maps, the following observations were made of the state level initiatives. First, 23 states and District of Columbia (hereafter DC) have legislative greenhouse gas emission targets, of which 15 states and DC have 2050 targets. There are a wide variety of targets used by this cohort, reflecting varying ambitions for emissions reductions. Second, there are two cap and trade schemes in the country, the California Cap and Trade Programme and the Regional Greenhouse Gas Initiative (with a membership made up of Connecticut, Delaware, Maine, Maryland, Massachusetts, New Hampshire, New York, Rhode Island, and Vermont). Table 1 summarizes the emissions, sectors and targets for these schemes. 
[Table 1 about here]

Third, 41 states and are members of the Climate Registry, a common system to support greenhouse gas emissions reporting, on either a mandatory (18 states) or voluntary basis (22 states and DC). A further two states (Texas and West Virginia) have voluntary greenhouse gas emissions registers. Finally, 34 states and have climate action plans.

CMCPA, launched in 2005, was established to promote action on climate change by committing to reduce greenhouse gas emissions and push for climate change legislation at state and national level (see http://www.usmayors.org/climateprotection/agreement.htm). Signatories to the Agreement include 1,037 municipalities in the USA (plus a small number from United States' territories), ranging in size from New York City to small townships. $\mathrm{C} 40$ is a worldwide network of 75 large cities working to tackle climate change (see http://www.c40.org), which includes 12 US cities. Of the 12 US C40 cities, only Houston is not also in CMCPA (see Slocum, 2004, for a review of this initiative).

The number of people living in states and/or municipalities covered by each of the climate change initiatives outlined above, as well as those included in all of them and none of them was calculated (taking in to account any double counting of the population). Data from the 2010 US Census population estimates for $1^{\text {st }}$ July 2014 were used to calculate the proportions of the total US population covered by state level initiatives and $\mathrm{C} 40$ on that date. The CMCPA website provides population data for the municipalities that have signed up to its initiative but its providence is 
unknown. The sum of the populations on the CMCPA website for its 100 largest municipalities was compared to the sum of the populations from the $1^{\text {st }}$ July 2014 census estimate: The census estimate sum was larger than the CMCPA sum by a factor of 1.08. Therefore, all 'CMCPA populations' in this paper have been multiplied by 1.08 , putting them on a comparative footing with the Census population estimates. Table 2 summarises the calculations undertaken, showing the percentage of population included within each initiative and combinations thereof.

[Table 2 about here]

It is evident from the data that sub-federal GCC responsiveness covers a substantial percentage of the population of the USA. At the upper end there is a substantial minority $(25.8 \%)$ where all state level the initiatives are in effect. At the lower end, only $4.4 \%$ of the population is untouched by state and/or municipality responsiveness. Table 3 shows the states and DC arranged into a typology of degree of engagement with surveyed initiatives alongside population estimates.

[Table 3 about here]

Drawing from the Lutsey and Sperling (2008), we can also make some observations about broad trends in population coverage over time. For example, state level emissions reduction targets have increased from $45 \%$ to $55.2 \%$ of the population in the seven year period. Likewise comparable movements for state greenhouse gas action plans are from $64 \%$ to $72.2 \%$; CMCPA coverage has increased from $26 \%$ to 
$30.5 \%$; and coverage of cap and trade schemes (with the addition of the Californian scheme) has increased from $16 \%$ to $25.1 \%$ of the population.

\section{Exploring organisational and accounting intersections}

This part of the paper follows Bebbington and Larrinaga (2014) in taking an issue of substance and drawing out connections for organisations and accounting scholars as well as sketching the potential links between the findings on population coverage and the responsiveness of municipalities (as novel accounting entities).

To the best of our knowledge, there are no standard ways to translate population coverage numbers into propositions for the number of organisations likely to be affected by state and municipality GCC responsiveness. Any carbon impact of individuals is mediated by organisations but these are distinctly different counting entities and hence any relationship between them is indeterminate. What seems likely (as a working hypothesis that can be interrogated) in that organisations that operate in states that have adopted more GCC initiatives (characterised as fully engaged and engaged in Table 3) are likely to encourage organisations operating in their territory to be proactive and may also offer incentives for them to do so. Incentives may take a variety of forms including partnerships to develop low carbon infrastructure or to coinvest in renewable energy (for example, CDP (2016: 13) document joint investment projects between state authorities and organisations). Alternatively, the translation of state and municipality influence into 'green clubs' (Prakash and Potoski, 2012) is likely to engender organisational level activities. In this context, organisations are encouraged by state action. At a more formal level, organisations in states that have cap and trade schemes will be subject to regulation (see also Freedman and Park, 
2014) and accounting issues arise in this context (see, for example, Bebbington and Larrinaga, 2008; Lovell et al. 2013).

Finally, the possibility that municipalities themselves may provide a novel setting for investigation of GCC responsiveness. While there is a longstanding literature on public sector environmental accounting (Ball et al. 2009), it is also the case that a municipality itself might constitute an entity for investigation. This supra-entity could be seen to encompass organisations and individuals alike in a joint programme of management and transformation. Cities have attracted some attention in the accounting literature (see Lapsley et al. 2010 in a special issue of Accounting, Auditing and Accountability Journal - 23(3), 2010). It may also be the case that some questions regarding accountability emerge at the level of a municipality, rather than at accounting entity level (see, for example, Baker, 2014).

\section{Concluding comments}

As we collectively seek to reduce "net global emissions to zero by $2060-2080$ ", (Clémençon, 2016, 17) more 'work' than has been seen to date is required. This paper focused on the question of GCC responsiveness in the USA and demonstrates that the population 'coverage' of initiatives at the sub-federal level is significant and has increased in the last decade. As Lutsey and Sperling observe, the USA "has been more committed to climate change mitigation than is generally acknowledged" (2008, 673). The "question remains how such forerunner clubs and other initiatives [the 'alliance of the ambitious'] ... can feed back into the multinational process so that the positive dynamics generated at various levels are allowed to spill-over and contribute to raising the ambition" (Hermville et al. 2015, 15). Initiatives such as those outlined 
in this paper to do, however, create a context within which more citizens might come to understand GCC and how it can be tackled (compared to being sceptical, see Tranter and Booth, 2015) as well as creating the knowledge, experience and learning in states and municipalities of how mitigation might be pursued. In this vein Lutsey and Sperling argue that there "must be a local commitment, down to individuals, to accomplish the type of economic and societal transformations that will be necessary to achieve very large reductions in carbon. The more engaged and the more powerful the commitment, the more likely it is that actual change will occur" $(2007,674)$. At the same time, Jordan et al. $(2015,977)$ note that while "polycentric governance offers new opportunities for climate action ... it is too early to judge [its effectiveness]".

This paper explores GCC responsiveness in the USA and its relevance to the concerns of accounting researchers. It can be tempting to believe that there is no scope for empirical research in carbon accounting/accountability in the USA if one takes the Federal level as the unit of analysis. If, however, a slightly different entity approach is taken (that of states and municipalities) then the possibility for documenting, understanding and tracing evolving carbon governance and performance exists. Moreover, there is likely to be an influence on organisations that are operating within territories that are seeking to be responsive to GCC. Understanding how and why organisations respond to GCC (and the accounting dimensions of their responses) in the absence of a mandated, Federal level programme of action will provide evidence of how action might still emerge nevertheless. 


\section{References}

Baker, R. (2014). Breakdowns of accountability in the face of natural disasters: The case of Hurricane Katrina. Critical Perspectives on Accounting, 25(7), 620-632. doi: 10.1016/j.cpa.2014.02.005

Ball, A., Mason, I., Grubnic, S. \& Hughes, P. (2009). The Carbon Neutral Public Sector: Early developments and an urgent agenda for research. Public Management Review, 11(5), 575-600. doi: 10.1080/14719030902798263

Bebbington, J., \& Larrinaga, C. (2008). Carbon trading: accounting and reporting issues. European Accounting Review, 17(4), 697-717. doi:

\section{$10.1080 / 09638180802489162$}

Bebbington, J., \& Larrinaga, C. (2014). Accounting and sustainable development: an exploration. Accounting, Organizations and Society, 39 (6), 395-413. doi: 10.1016/j.aos.2014.01.003

Buxton, N. (2016). COP 21 Charades: Spin, Lies and Real Hope in Paris. Globalizations..13(6), 934-937. doi: 10.1080/14747731.2016.1161936

CDP. (2016). It takes a city: The case for collaborative climate action. London: Author

Clémençon, R. (2016). The Two Sides of the Paris Climate Agreement: Dismal Failure or Historical Breakthrough? Journal of Environment \& Development, 25, 314. doi: $10.1177 / 1070496516631362$

Freedman, M. \& Park, J. (2014). Mandated Climate Change Disclosures by Firms Participating in the Regional Greenhouse Gas Initiative. Social and Environmental 
Accountability Journal, 34(1), 29-44.

Green, J., Sterner, T., \& Wagner, G. (2014). Balance of bottom-up and top-down in linking climate policies. Nature Climate Change 4, 1064-1067. doi:

10.1038/nclimate2429

Hermwille, L. Obergassel, W., Ott, H. \& Beuermann, C. (2015). UNFCCC before and after Paris - what's necessary for an effective climate regime? Climate Policy, doi: $10.1080 / 14693062.2015 .1115231$

Jordan, A., Huitema, D., Hiden, M., van Asserlt, H., Rayner, T., Schoenefeld, J., Tosun, J., Forster, J., and Boasson, E. (2015). Emergence of polycentric climate governance and its future prospects. Nature Climate Change, 5, 977-982. doi: $10.1038 /$ nclimate2725

Krause, R. (2011). Symbolic or substantive policy? Measuring the extent of local commitment to climate protection. Environment and Planning C: Government and Policy 29, 46-62. doi: 10.1068/c09185

Lapsley, I., Miller, P., \& Panozzo, F. (2010). Accounting for the City. Accounting, Auditing and Accountability Journal, 23(3), 305-324. doi:

$10.1108 / 09513571011034316$

Lovell, H., Bebbington, J., Larrinaga, C., and Sales de Aguiar, T. (2013). Putting carbon markets into practice: a case study of financial accounting in Europe.

Environment and Planning C, 31(4), 741-757. doi 10.1068/c1275

Lutsey, N., \& Sperling, D. (2008). America's bottom-up climate change mitigation policy. Energy Policy, 36, 673-685. doi:10.1016/j.enpol.2007.10.018 
Morgan, J. (2016). Paris COP 21: Power that Speaks the Truth? Globalizations, in press. doi: 10.1080/14747731.2016.1163863

Netherlands Environmental Assessment Agency (2015). Trends in Global $\mathrm{CO}_{2}$ Emissions: 2015 Report. The Hague: Author.

Prakash, A., \& Potoski, M. (2011). Voluntary Environmental Programs: A Comparative Perspective. Journal of Policy Analysis and Management, 31(1), 123138. doi: 10.1002/pam.20617

Rajamani, L. (2016). Ambition and differentiation in the 2015 Paris Agreement: interpretative possibilities and underlying politics. International and Comparative Law Quarterly, 65, 493-514. doi: 10.1017/S0020589316000130

Slocum, R. (2004). Consumer citizens and the Cities for Climate Protection campaign. Environment and Planning A, 36, 763-782. doi: 10.1068/a36139

Spash, C. (2016). This Changes Nothing: The Paris Agreement to Ignore Reality. Globalizations, in press. doi: 10.1080/14747731.2016.1161119

Tranter, B. and Booth, K. (2015). Scepticism in a changing climate: A cross-national study. Global Environmental Change, 33, 154-164. doi:

10.1016/j.gloenvcha.2015.05.003

UNFCCC. (2015, December 12). Adoption of the Paris agreement and annex: Paris agreement. Paris: Author. 
Table 1: Summary of United States of America cap and trade schemes (data sources: $\underline{\text { http://www.c2es.org/us-states-regions/key-legislation/california-cap-trade }}$ and https://www.rggi.org/docs/Documents/RGGI_Fact_Sheet.pdf).

\begin{tabular}{|c|c|c|}
\hline & $\begin{array}{l}\text { California Cap and Trade } \\
\text { Programme }\end{array}$ & $\begin{array}{l}\text { Regional Greenhouse Gas } \\
\text { Initiative }\end{array}$ \\
\hline $\begin{array}{l}\text { Greenhouse } \\
\text { Gases } \\
\text { included }\end{array}$ & $\begin{array}{l}\text { Carbon dioxide }\left(\mathrm{CO}_{2}\right) \text {, methane } \\
\left(\mathrm{CH}_{4}\right) \text {, nitrous oxide }\left(\mathrm{N}_{2} \mathrm{O}\right) \text {, } \\
\text { sulphur hexafluoride }\left(\mathrm{SF}_{6}\right) \text {, } \\
\text { perfluocarbons }(\mathrm{PFCs}) \text {, nitrogen } \\
\text { trifluoride }\left(\mathrm{NF}_{3}\right) \text {, other fluorinated } \\
\text { greenhouse gases }\end{array}$ & Carbon dioxide $\left(\mathrm{CO}_{2}\right)$ only \\
\hline Sectors & $\begin{array}{l}\text { Electricity (including imports) and } \\
\text { industry emitting 25,000 MTCO2e } \\
\text { or more annually, distributors of } \\
\text { transportation, natural gas, and } \\
\text { other fuels }\end{array}$ & $\begin{array}{l}\text { Fossil fuel-fired power plants, } 25 \\
\text { megawatts or greater in size (does } \\
\text { not include imports) }\end{array}$ \\
\hline Target & $\begin{array}{l}\text { Approximately } 17 \% \text { below } 2013 \\
\text { emissions by } 2020\end{array}$ & $\begin{array}{l}15 \% \text { below } 2013 \text { emissions by } \\
2020\end{array}$ \\
\hline
\end{tabular}


Table 2: Estimates of proportions of the United States population covered by 
state or municipality GCC initiatives (source: authors' own calculations). 


\begin{tabular}{|c|c|c|}
\hline Initiative & Population figures & $\begin{array}{l}\text { Percentage of United } \\
\text { States' population } \\
\text { represented }\end{array}$ \\
\hline $\begin{array}{l}\text { Greenhouse gas emissions } \\
\text { reporting }\end{array}$ & $297,439,185$ & 93.3 \\
\hline Climate action plans & $230,244,078$ & 72.2 \\
\hline $\begin{array}{l}\text { Legislative greenhouse gas } \\
\text { emissions target }\end{array}$ & $175,860,873$ & 55.2 \\
\hline Cap and trade schemes & $79,205,856$ & 25.8 \\
\hline $\begin{array}{l}\text { All of the state based } \\
\text { initiatives (this number is } \\
\text { the same as those in cap and } \\
\text { trade schemes as all the } \\
\text { other initiatives provide a } \\
\text { basis for such schemes) }\end{array}$ & $79,205,856$ & 25.8 \\
\hline $\begin{array}{l}\text { None of the state based } \\
\text { initiatives }\end{array}$ & $17,653,203$ & 5.6 \\
\hline CMCPA and C40 combined & $89,898,730$ & 30.5 \\
\hline $\begin{array}{l}\text { None of the above state or } \\
\text { municipality based } \\
\text { initiatives }\end{array}$ & $13,870,374$ & 4.4 \\
\hline
\end{tabular}


Table 3: Outline of States by degree of engagement with surveyed initiatives 


\begin{tabular}{|c|c|c|}
\hline Description & States & $\begin{array}{l}\text { Population (\% } \\
\text { of US) }\end{array}$ \\
\hline $\begin{array}{l}\text { Fully engaged - Take } \\
\text { part in all four state } \\
\text { level initiatives }\end{array}$ & $\begin{array}{l}\text { California, Connecticut, } \\
\text { Maine, Maryland, } \\
\text { Massachusetts, } \\
\text { New Hampshire, New York, } \\
\text { Rhode Island, Vermont }\end{array}$ & $\begin{array}{l}79,205,856 \\
(25.8 \%)\end{array}$ \\
\hline $\begin{array}{l}\text { Engaged - have an } \\
\text { emission plan and/or } \\
\text { mandatory reporting, } \\
\text { in additional to an } \\
\text { action plan and being } \\
\text { on the climate registry } \\
\text { (Delaware is also in the } \\
\text { Regional Greenhouse } \\
\text { Gas Initiative) }\end{array}$ & $\begin{array}{l}\text { Arizona, Colorado, Delaware, } \\
\text { Florida, Hawaii, Illinois, } \\
\text { Iowa, Michigan, Minnesota, } \\
\text { Montana, New Jersey, } \\
\text { New Mexico, North Carolina, } \\
\text { Oregon, Utah, Virginia, } \\
\text { Washington, Wisconsin, DC }\end{array}$ & $\begin{array}{l}116,399,285 \\
(36.5 \%)\end{array}$ \\
\hline $\begin{array}{l}\text { Exploring Engagement } \\
\text { - have a climate action } \\
\text { plan and/or are on the } \\
\text { climate registry (Texas } \\
\text { and West Virginia } \\
\text { have individual, } \\
\text { voluntary registers) }\end{array}$ & $\begin{array}{l}\text { Alabama, Alaska, Arkansas, } \\
\text { Georgia, Idaho, Kansas, } \\
\text { Kentucky, Missouri, Nevada, } \\
\text { Ohio, Oklahoma, } \\
\text { Pennsylvania, South } \\
\text { Carolina, Tennessee, Texas, } \\
\text { West Virginia, Wyoming }\end{array}$ & $\begin{array}{l}105,537,145 \\
(33.1 \%)\end{array}$ \\
\hline
\end{tabular}




\begin{tabular}{|l|l|l|}
\hline Yet to Engage - no & Indiana, Louisiana, & $17,714,770$ \\
state level initiatives & Mississippi, Nebraska, & $(5.6 \%)$ \\
& North Dakota, South Dakota & \\
& & \\
\hline
\end{tabular}

